\title{
YESUS SEBAGAI GURU TELADAN DALAM PERSPEKTIF PANTEKOSTA KHARISMATIK
}

\author{
Talizaro Tafonao
}

\begin{abstract}
Abstrak
Dalam tulisan ini, penulis melakukan kajian terhadap Injil Sinoptik tentang Yesus sebagai guru teladan dalam perspektif pantekosta kharismatik. Kajian ini berangkat dari kegelisahan penulis terhadap kondisi para pelayan Tuhan/pengajar, di mana para pendidik sekarang ini telah hilang arah dalam menunaikan tugas sebagai guru. Akibatnya, guru tidak lagi menjadi figur atau teladan bagi peserta didik dan kepada masyarakat pada umumnya. Dengan persoalan itu maka penulis mengupas tentang Yesus sebagai guru teladan dalam pengalaman empiris. Berdasarkan kajian yang dilakukan oleh penulis dalam tulisan ini, maka ada dua hal penting yang perlu dipelajari, yakni Yesus sebagai pendoa. Keteladanan Yesus sebagai pendoa telah menginspirasi banyak orang termasuk para pelayan-pelayan di kalangan kaum pantekosta kharismatik secara khusus guruguru Agama Kristen. Selanjutnya, Yesus sebagai ahli pengajar. Mengajar merupakan tugas yang amat penting dalam pelayanan-Nya selama Dia ada di dunia. Keunikan Yesus sebagai guru teladan telah banyak mempengaruhi perilaku manusia dari generasi ke generasi, bahkan orang-orang tersebut telah menjadi pelaku dari perubahan itu sampai sekarang ini. Hal ini nampak dari aktivitas orang-orang Pantekosta yang sangat dinamis dan populer dalam meneruskan kegiatan reformasi gereja. Oleh karena itu, tulisan ini merupakan studi pantekosta kharismatis dengan memasukkan aktivitas tokoh agama populer sebagai objek kajian baru yang selama ini lebih menekankan popularitas dan pribadi sang tokoh secara biografis sebagai sentral.
\end{abstract}

Kata Kunci: Yesus, Guru, Teladan dan Pantekosta Kharismatik

\section{Pendahuluan}

Sampai detik ini orang-orang pantekosta kharismatik mengakui bahwa Yesus Kristus sebagai sosok guru teladan dalam kehidupan kekristenan saat ini. Sekalipun pandangan ini masih ditentang oleh orang-orang modern, yang hidupnya di luar kekristenan. Tetapi khotbah-khotbah para pendeta kharismatik saat ini tidak pernah mengesampingkan Yesus sebagai guru teladan dalam hidupnya. Bahkan para penceramah-penceramah pantekosta kharismatik saat ini begitu gencar menyuarakan bahwa Yesus sebagai guru teladan dalam hidup ini. Inilah ciri khas dari orang-orang pantekosta kharismatik yang selalu dipandang terlalu "berapi-api". 
Kristen Kharismatik adalah aliran agama Kristen yang bercirikan (menonjolkan) karunia rohani atau "gerakan roh".40 Kata Kharismatik berasal dari bahasa Yunani; $\chi \alpha ́ \alpha \iota \sigma \mu \alpha=$ Kharisma=karunia roh. ${ }^{41}$ Orang-orang pantekosta kharismatik memandang Kristus sebagai Pribadi yang memberikan karunia-karunia rohani kepada gereja/umat-Nya untuk membawakan perbaikan melalui Roh, sesuai dengan hak istimewa dan anugerah ilahi. Tentu hal ini menjadi pegangan penting bagi orang-orang pantekosta kharismatik sehingga aliran ini sangat yakin bahwa pelayanan Yesus di dunia ini menjadi salah satu pendorong bagi para pengajar/pelayan untuk belajar dari keteladanan Yesus sebagai guru di dalam Injil Sinoptik. Pengajaran/pelayanan Yesus merupakan tugas utama-Nya sebagai guru, hal ini dapat dilihat dalam Injil Sinoptik, yakni Injil Matius, Markus dan Lukas. Keteladanan Yesus yang terdapat dalam Injil Sinoptik ini dapat dijadikan sebagai contoh dalam mengajar oleh guru-guru Agama Kristen. Menjadi guru adalah sebuah panggilan jiwa. Khoe Yao Tung menjelaskan bahwa "menjadi pendidik Kristen bukanlah pilihan, melainkan panggilan untuk bersaksi". ${ }^{42}$ Mutu guru Pendidikan Agama Kristen sebagai hamba Tuhan juga perlu ditilik dari hidup kerohanian atau spiritualitasnya. ${ }^{43}$

Defini spiritualitas yang didasarkan pada Alkitab maka J. Gerald Janzen menuliskan: It can hardly be doubted that the Shema constitutes the theological center of the Book of Deuteronomy: "Hear, O Israel: Yahweh our God, Yahweh is one; and you shall love Yahweh your God with all your heart, and with all your soul, and with all your strength" (6:4-5)... Every act of Torah-obedience finds its motivation, its purpose, and its criterion of appropriateness in Israel's love for Yahweh. ${ }^{44}$ Kasih kepada Allah menjadi motivasi, tujuan dan kriteria kasih orang Israel untuk Allah. Kasih Allah itu di dalam, tidak hanya yang tampak di luar. Spiritualitas itu mengasihi Allah dan sesama (Matius 22:37-39).

Seorang guru Kristen, terutama guru Pendidikan Agama Kristen, selalu dituntut darinya sesuatu yang berkaitan dengan kepribadiannya yang diwujudkan dalam cara hidupnya, dengan pertanggung jawaban keagamaan dan moral. Kualitas hidup serta kinerjanya diharapkan berbeda dari guru lain, karena pekerjaannya harus dipertanggung

${ }^{40}$ Rahner. Karl, Encyclopedia of theology: A concise Sacramentum mundi, (USA: Continum International Publishing Inc, 1975),

${ }^{41}$ Samuel. Wilfred J., Kristen Kharismatik, Jakarta: BPK Gunung Mulia, 2006

${ }^{42}$ Khoe Yao Tung, Terpanggil Menjadi Pendidik Kristen Yang Berhati Gembala, (Yogyakarta: Andi Offset, 2016), hlm. 2

${ }^{43}$ B. Samuel Sidjabat, Strategi Pendidikan Kristen Suatu Tinjauan Teologis-Filosofis (Yogyakarta: Andi, 1999), hlm. 137.

${ }^{44}$ Bruce Waltke mengutip J. G. Janzen, "The Yoke That Gives Rest," Int 41 (1987), hal. 256; Bruce Waltke, "Evangelical Spirituality: A Biblical Scholar's Perspective," JETS 31/1 (March 1988), hal. 9.
} 
jawabkan kepada Tuhan, Sang Guru Agung pemberi pekerjaan itu. Sebab, pendidikan Kristen adalah memuridkan, menggerakkan anak-anak dekat dengan Tuhan. Mendidik anak dalam Kristus adalah mendidik dalam kepemimpinan yang spiritual. ${ }^{45}$ Stephen Tong menjelaskan, guru agama Kristen adalah seorang yang di dalam dirinya sendiri memiliki keyakinan, kepercayaan yang teguh, ibadah yang baik, memiliki sifat moral yang baik dan hidup dalam kesucian, memiliki kebajikan yang sesuai dengan agamanya sehingga ia mengerjakan segala sesuatu dengan bertanggung jawab untuk kekekalan. ${ }^{46}$

Sedangkan kaum pantekosta kharismatik lebih menekankan kepada kehidupan yang dikuasai oleh Roh Kudus. Semua orang, yang dipimpin Roh Allah, adalah anak Allah. Sebab kamu tidak menerima roh perbudakan yang membuat kamu menjadi takut lagi, tetapi kamu telah menerima Roh yang menjadikan kamu anak Allah. Oleh Roh itu kita berseru: "ya Abba, ya Bapa (Rom. 8:14-15). Hal ini sering dikaitkan dengan ayat dalam Injil Yohanes 4: 24, "Allah itu Roh dan barang siapa menyembah Dia, haruslah menyembah-Nya dalam roh dan kebenaran. ${ }^{47}$ Kehadiran Allah terjadi ketika manusia melakukan Pujian dan Penyembahan. ${ }^{48}$ Ini ciri orang-orang kaum pantekosta Kharismatik, yakni menekankan hubungan pribadi dengan Tuhan.

Kaum pantekosta kharismatik berpendapat bahwa hidup di dalam Tuhan jauh lebih penting daripada hanya sekedar memiliki pengetahuan. Guru Agama Kristen harus menyadari hal ini sebagai dasar dalam memenuhi panggilannya sebagai pendidik. Seorang guru harus tahu bagaimana sepatutnya mengemban tugasnya sebagai guru berdasarkan iman kristiani, yakni bukan hanya mengajarkan apa yang diketahuinya, tetapi juga harus memberikan dan mengajarkan apa yang dia miliki. Guru Kristen harus mampu menjadi teladan dan menunjukkan kepribadiannya sebagai pendidik serta bercermin pada figur Yesus yang mempunyai kepribadian yang tinggi. Kata keteladanan dapat diartikan sebagai contoh bagi seseorang yang dapat digugu dan ditiru. ${ }^{49}$ Kata keteladanan berasal dari kata teladan yang dalam Kamus Besar Bahasa Indonesia berarti "perbuatan yang patut ditiru, dicontoh."50 Sedangkan kata "keteladanan" diartikan "hal-

\footnotetext{
${ }^{45}$ Loc.cit, Khoe Yao Tung

${ }^{46}$ Stephen Tong, Arsitek Jiwa II, (Surabaya: Momentum, 2008), hlm. 9

${ }^{47}$ Herlianto., Teologi Sukses, Jakarta: BPK Gunung Mulia, 2006

${ }^{48}$ Munroe. Myles., The Purpose and Power of Praise \& Worship, (USA: Destiny Image Publisher Inc, 2000), Hlm. xiii 2008), hlm. 17

${ }^{49}$ Hamzah B. Uno, Profesi Kependidikan: Problema, Solusi, dan Reformasi Pendidikan di Indonesia, (Jakarta: Bumi Aksara,

${ }^{50}$ Tim Penyusun Kamus Pusat Bahasa, Kamus Besar BahasaIndonesia, (Jakarta: Balai Pustaka, 2001), 1160.
} 
hal yang dapat ditiru atau dicontoh." 51 Kata "teladan" dalam bahasa Yunani berasal dari kata u’po, deigma (hupodeingma) yang diterjemahkan "teladan, contoh, tiruan."52 Di dalam Perjanjian Baru kata ini hanya muncul enam (6) kali (Yoh. 13:15; Ibr. 4:11; 8:5; 9:23; Yak. 5:10; 2Ptr. 2:6). Nurlaela Isnawati mengemukakan bahwa keteladanan merupakan panutan yang baik dihadapan seseorang. ${ }^{53}$ Dengan demikian keteladanan merupakan role model yang memberikan contoh dalam hal sikap, perilaku, dan pembentukan kepribadian seseorang. ${ }^{54}$ Oleh karena itu, dalam perspektif pantekosta kharismatik memandang Yesus sebagai guru teladan.

Oleh karena itu, agar tulisan ini dapat dipahami, maka penulis menggunakan metode penelitian naratif. Penelitian naratif adalah laporan bersifat narasi yang menceritakan urutan peristiwa secara terperinci. Dalam desain penelitian naratif, peneliti menggambarkan kehidupan individu, mengumpulkan cerita tentang kehidupan orang-orang dan menuliskan cerita pengalaman individu. ${ }^{55}$ Menurut Rizal Maward (dikutip dalam James Schreiber dan Kimberly Asner-Self, 2011) penelitian Naratif adalah studi tentang kehidupan individu seperti yang diceritakan melalui kisah-kisah pengalaman mereka, termasuk diskusi tentang makna pengalaman-pengalaman bagi individu. ${ }^{56}$ Berdasarkan kedua pendapat tersebut di atas maka tulisan ini menceritakan ulang kejadian atau peristiwa yang sudah pernah terjadi dan kemudian penulis menarasikannya dalam sebuah tulisan sebagai bentuk laporan ilmiah.

\section{Yesus Sebagai Pendoa}

Kata pendoa secara umum bararti orang yang senantiasa berdoa kepada sesembahannya untuk menaikkan pujian, permintaan, dan harapan. Sebab pendoa adalah kata kerja yang bermakna terus-menerus berdoa. Berdoa kepada Tuhan adalah sebagai alat komunikasi kepada Tuhan. Berdoa dalam kekristenan berarti seseorang yang senantiasa berdoa untuk menaikan pujian, permintaan, dan harapannya kepada Allah pencipta langit dan bumi. Doa dalam kamus besar bahasa Indonesia yang artinya:

\footnotetext{
${ }^{51}$ Ibid. Kamus,

${ }^{52}$ Hasan Sutanto, Perjanjian Baru Interlinear Yunani-Indonesia dan Konkordansi Perjanjian Baru II, (Jakarta: LAI, 2004), hal. 780.

${ }^{53}$ Nurlaela Isnawati, Guru Positif-Motivatif, (Yogyakarta: Laksana, 2010), hlm. 130

${ }^{54}$ Suparlan, Menjadi Guru Efektif, (Yogyakarta: Hikayat, 2005), hlm. 34

${ }^{55}$ Clandinin, D.J. \& Conelly, F.M. Narrative Inquiry Experience and Story in Qualitative Research. San Fransisco: Jossey-Bass Publishers, 2000

${ }^{56}$ Rizal maward, Metodologi Penelitian Pendekatan Naratif Fenomenology, (Surabaya: Universitasi Airlangga, 2017), hlm. 4
} 
Pemohonan (harapan, permintaan, pujian) kepada Tuhan". ${ }^{57}$ Jadi kalimat teladan Yesus sebagai pendoa, berarti Yesus selalu berhubungan dengan Allah Bapa sewaktu Ia berada di dunia melalui doa setiap saat sebelum melakukan pekerjaan-Nya sebagai pengajar. Berikut ini beberapa doa Yesus yang patut ditiru atau diikuti, yang terdapat dalam Injil Sinoptik, yaitu:

1. Yesus mengajarkan berdoa di pagi hari

Sebelum Yesus melakukan pekerjaan-Nya, Yesus mengambil waktu untuk berdoa. Doa Yesus di pagi hari yang ditulis oleh Injil Markus dikatakan dalam pasal 1 ayat 35 menyatakan, "Pagi-pagi benar, waktu hari masih gelap, Ia bangun dan pergi ke luar. Ia pergi ke tempat yang sunyi dan berdoa di sana." Hal ini berarti bahwa, sebelum Ia melakukan aktivitas pelayanan-Nya, Ia mengawalinya dengan doa. Tempat yang sunyi merupakan tempat yang ideal untuk melakukan doa agar komunikasi dengan Allah dapat berlangsung dengan baik. Waktu pagi hari dipilih untuk berdoa, karena pagi hari adalah waktu di mana keadaan masih sepih dan awal semua kegiatan akan segera dimulai dan Yesus tahu bahwa itulah waktu yang tenang untuk membangun hubungan pribadi dengan Allah melalui doa. Menurut hemat Jack Hayford mengatakan doa pada intinya merupakan hubungan anak Allah yang sudah ditebus, yang bekerja bersama dengan Allah untuk mewujudkan rencana penebus-Nya di bumi. ${ }^{58}$

Markus Pasal 1 ayat 35 ditafsirkan oleh penafsir yang menyatakan bahwa, keberangkatan dengan diam-diam dan perjalanan keliling Galilea. Di luar dugaan, bahwa di tengah kesibukan demikian, Yesus sudah bangun pada waktu hari masih gelap dan menyelinap ke luar kota sebelum orang lain bangun. Cerita itu mencerminkan pandangan mereka yang ada di rumah, dan menemukan bahwa Ia telah pergi, berpendapat berkata bahwa Ia tidak membuang kesempatan-kesempatan yang berharga di Kapernaum karena tidak menyadari betapa Ia dicari-cari. ${ }^{59}$ Yesus berdoa seorang diri untuk memberikan teladan kepada murid-murid-Nya.

${ }^{57}$ Tim Penyusun, Kamus besar Bahasa Indonesia, (Jakarta: Balai Pustaka, 1995), hlm. 239

${ }^{58}$ Jack Hayford, Doa Mengalahkan Kemustahikan, (Yogyakarta: Andi Offset, 2008), hlm. 118

${ }^{59}$ Tafsiran Masa Kini 3, Matius-Wahyu, (Jakata: Yayasan Komunikasi Bina Kasih/OMF, 1994), hlm. 132 
Doa seperti ini masih menjadi aktivitas rutin yang harus dilakukan oleh kalangan pantekosta kharismatik. Bukan hanya itu saja, tema-tema tentang doa sudah menjadi tema utama dalam khotbah-khotbah para hamba Tuhan pantekosta kharismatik. Makanya tidak mengherankan jika setiap orang percaya/jemaat diwajibkan doa setiap pagi (saat teduh). Di beberapa gereja pantekosta kharismatik misalnya Gereja pantekosta di Indonesia (GPdI) Gunung Kidul, pada saat itu penulis sebagai mahasiswa praktek yang diutus oleh kampus di gereja tersebut pada tahun 2006, setiap pagi mulai jam 04.3006.00 wib jemaat datang ke gereja untuk berdoa bersama dengan gembalanya dan hal ini dilakuakan setiap hari mulai hari senin sampai hari sabtu.

Begitu pula dengan Gereja Bethel Indonesia (GBI) Temanggung, pada tahun 2007, penulis dan rekan mahasiswa lain yang di utus oleh kampus untuk praktek di sana, setiap pagi jemaat beserta dengan gembala sidang berdoa keliling di rumah-rumah jemaat di mulai dari jam 04.30-06-30 Wib. Selanjutnya, gerakan doa seperti ini dapat ditemui di beberapa sekolah-sekolah tinggi teologi yang ada di Indonesia seperti STT Kadesi Yogyakarta, STTII, STTNI, STT Galilea, STT Berita Hidup, STT Intheos, STT Salatiga, STT Bethel Jakarta, STT KAO, STT Simpson, STT Kanaan Ungaran, doa pagi masih menjadi salah satu aktivitas penting dalam membangun sipiritual mahasiswa. Mahasiswa diwajibkan bangun setiap pagi mulai dari jam 04.30-06.00 wib untuk berdoa bersama dengan mahasiswa lainnya. ${ }^{60}$

Doa pagi bagi kaum pantekosta kharismatik bukan hanya sekedar rutinitas semata, namun doa sebagai bentuk dari penghayatan iman dalam Yesus Kristus, yang diwujudkan dalam sebuah komunitasi rohani. Komunitasi rohani seperti ini dapat memberi dampak positif kepada setiap orang percaya agar dirinya mengalami kedewasaan rohani. Dalam pandangan orang-orang pantekosta kharismatik berdoa di pagi hari adalah sebagai bentuk penghormatan kepada Allah yang memberi hidup dan berkat sekaligus sebagai pedoman hidup seseorang sebelum melakukan segala sesuatu. Berbeda dengan orang-orang Kristen Protestan pada umumnya, yang hanya menganggap doa sebagai rutinitas. Pandangan itu ditepis oleh Gondowijoyo mengatakan bahwa melalui doa Allah akan melakukan perkara-perkara ajaib dan luar biasa. Dalam sejarah

${ }^{60}$ Pada tahun 2013 samapai 2018, penulis salah satu staf yang tinggal di asrama dan sekaligus sebagai pembina kehohanian mahasiswa, yakni di STT Kadesi Yogyakarta. Setiap pagi mahasiswa harus bangun pagi untuk berdoa bersama. Sebagai staf yang tinggal di asrama tentu harus ikut berdoa bersama dengan mahasiswa. Hal sama juga dilakukan oleh beberapa STT lain. 
kebangunan, justru di tengah masa sukar, gereja bangkit bersatu, mencari wajah Allah dan menggerakkan hati Allah melalui doa yang mereka panjatkan dengan segenap hati.61

Berdasarkan apa yang diutarakan oleh Gondowijoyo di atas benar adanya bahwa gereja-gereja kaum pantekosta kharismatik sering melakukan Kebaktian Kebangunan Rohani (KKR) di tempat-tempat terbuka. Misalnya Gereja Tiberias Indonesia menggelar perayaan Natal secara besar-besaran di Stadion Gelora Bung Karno (GBK), Senayan, Sabtu (8/12/2018) malam. ${ }^{62}$ Gereja yang sama juga melakukan Kebaktian Kebangunan Rohani (KKR) pada awal tahun 2019, yang diadakan 25 Januari 2019, pk. 18.30 Wib.63 Selanjutnya, dalam berita koran bernama Wartanasrani.com menginformasikan bahwa (Forum Musyawarah Antar Gereja) bekerjasama dengan MANMIN Center Jakarta telah menggelar Kebaktian Kebangunan Rohani (KKR) Mujizat Kesembuhan dan Penyembahan, pada hari sabtu, 14 April 2018, mulai pukul 15.00 Wib sampai selesai.64

2. Yasus mengajarkan berdoa menjelang malam

Markus pasal 6 ayat 46, mencatat bahwa, "Setelah Ia berpisah dari mereka, Ia pergi ke bukit untuk berdoa." Sekali lagi ayat ini menunjukkan kepada penulis bahwa Yesus ketika Ia sendirian Ia pergi ke bukit untuk berdoa, dan dalam ayat selanjutnya berkata "Ketika hari sudah malam perahu itu sudah di tengah danau, sedang Yesus tinggal sendirian di darat" (Mark. 6:47). Ini menunjukkan bahwa Yesus berdoa menjelang malam hari untuk mengucap syukur atas apa yang telah Allah lakukan dalam mukjizat Yesus memberi makan lima ribu orang (Mrk. 6:30-44). Dari Markus pasal 6 ayat 46 penafsir mengatakan, "tapi Yesus mengenal saat yang paling berbahaya ini, saat yang mengharuskan paksaan terhadap para murid supaya pergi dan pengasingan-Nya sendiri ke tempat yang sunyi untuk berdoa". ${ }^{65}$ Doa yang lakukan oleh Yesus adalah merupakan doa pribadi. Doa perlu ada keheningan suasana agar dapat berkomunikasi dengan Allah tanpa ada gangguan dari apapun.

\footnotetext{
${ }^{61}$ Gondowijoyo, Sekolah Doa, (Yogyakarta: Andi Offset, 2010, hlm. 14

${ }^{62}$ https://news.okezone.com/read/2018/12/08/338/1988672/ratusan-ribu-jemaat-hadiri-acara-natal-di-gbk-350-aparat-gabunganditerjunkan, diunduh pada hari Jumat, 12 April 2019

${ }^{63}$ https://www.tiberias.or.id/events/rally-awal-kkr-tahun-2019-tiberias-medan-pajus-padang-bulan-25-januari-2019-jam-18-30wib--45, diunduh pada hari Jumat, 12 April 2019.

${ }^{64} \mathrm{https}$ ://wartanasrani.com/detailpost/manmin-center-jakarta-dan-formag-jaktim-kerjasama-gelar-kkr-mujizat-kesembuhan-danpenyembahan-2018, diunduh pada hari Jumat, 12 April 2019

${ }^{65} \mathrm{Ibid}$, Gondowijoyo, hlm. 148
} 
James Stalker mengatakan: Selama pelayanan-Nya doa telah menjadi kesenanganNya dan pendorong bagi-Nya. Pada masa yang paling sibuk sekalipun, ketika Ia begitu letih oleh pekerjaan pada siang hari sehingga menjelang malam Ia siap untuk langsung merebahkan diri-Nya karena amat kepayahan, namun Ia selalu berusaha meloloskan diri dari orang banyak serta murid-murid untuk pergi ke puncak gunung dan menghabiskan semalam suntuk untuk bersekutu dengan Bapa-Nya. Ia tidak pernah mengambil tindakan penting tanpa diawali dengan berdoa semalam suntuk. ${ }^{66}$ Menurut Robert Oh mengatakan doa Yesus memberikan kehidupan kepada diri-Nya sendiri maupun kepada orang-orang disekitar-Nya. Doa adalah nafas kehidupan bagi seseorang. ${ }^{67}$

Berdoa menjelang malam bagi Tuhan Yesus sangat penting karena Tuhan Yesus menyadari bahwa apa yang terjadi di sepanjang hari itu adalah semuanya pertolongan Bapa-Nya (Mar.6:41-44). Dia mengambil waktu berdoa untuk membangun hubungan pribadi dengan Allah Bapa. Hal-hal seperti ini masih dilakukan oleh beberapa gereja pantekosta kharismatik. Misalnya Gereja Bethel Indonesia Teleios Yogyakarta setiap menjelang malam team pengerja melakukan doa sebagai bentuk ucapan syukur kepada Allah. Hal ini sudah berjalan beberapa tahun belakangan ini sejak penulis bergabung di gereja tersebut mulai tahun 2015-sekarang. Selain itu, mahasiswa STT Kadesi Yogyakarta melakukan hal yang serupa. Setiap malam sebelum tidur mahasiswa wajib berdoa bersama dengan mahasiswa lainnya. Bahkan sebelum berdoa harus membaca Alkitab terlebih dahulu sebanyak 5 pasal.

Selain doa malam yang dilakukan oleh orang-orang pantekosta kharismatik, orang-orang pantekosta kharismatik juga melakukan doa keliling. Penulis masih ingat pada tahun 2008, Gereja Bagi Kristus (GBK) yang digembalakan oleh Pdt Tukiman di Tangerang, gereja ini masih tahap perintisan namun setiap malam minggu pasti setiap para pelayan di gereja tersebut diajak untuk berdoa keliling daerah itu. Hal yang sama juga dilakukan oleh Gereja Bethel Indonesia Teleios Yogyarta, pada tahun 2016 seluruh jemaat diajak doa keliling di alun-alun selatan Yogyakarta. Pada umumnya, doa keliling ini memiliki tujuan. Salah satu tujuan doa keliling bagi orang-orang pantekosta

\footnotetext{
${ }^{66}$ James Stalker, Masa Hidup Yesus Kristus, (Malang: Gandum Mas,1991), hlm. 89

${ }^{67}$ Robert Oh. Sukwan, The Prayer Drive Life, (Yogyakarta: Andi Offset, 2010), hlm. 15
} 
kharismatik adalah (1) Doa pendamaian, (2) Doa peperangan rohani, (3) Doa terobosan rohani.

Selanjutnya, selain doa malam dan doa keliling sebagaimana yang sudah dijelaskan di atas, penulis juga melihat bahwa kaum pantekosta kharismatik memiliki bukit doa seperti yang dilakukan oleh Tuhan Yesus dalam Markus pasal 6: 46. Dalam tulisan ini, penulis menguraikan beberapa tempat doa yang sering dikunjungin oleh orang-orang percaya, yaitu: (1) bukit doa Emalta (Kaliurang), (2) bukit doa Getsemani (Ungaran), (3) Bukit doa Anugerah (Jawa Timur). Menurut penjelasan dari salah satu pemilik bukit doa, yakni Gondowijoyo mengatakan bahwa tempat doa ini diperuntukkan kepada siapa saja yang sedang mengalami pergumulan hidup yang berat, yang sakit, dan lain sebagainya. 68 Tujuan dari bukit doa ini adalah agar jemaat Tuhan membangun hubungan pribadi dengan Tuhan seperti yang lakukan oleh Tuhan Yesus.

3. Yesus mengajarkan berdoa bersama dengan murid-Murid-Nya.

Pertama kali Yesus mengajak murid-muridnya untuk pergi berdoa di dalam Injil Markus pasal 14 ayat 32 dan ayat 35, "lalu sampailah Yesus dan murid-murid-Nya ke suatu tempat yang bernama Getsemani. Kata Yesus pada murid-murid-Nya: "Duduklah di sini, sementara Aku berdoa" ayat 32. Dan ayat 35 mengatakan, Ia maju sedikit merebahkan diri ke tanah dan berdoa supaya, sekiranya mungkin, saat itu lalu dari padaNya". Isi doa Yesus yang terdapat dalam ayat 36 sangat jelas mengtakan, "Kata-Nya: "Ya Abba, ya Bapa, tidak ada yang mustahil bagi-Mu, ambillah cawan ini dari pada-Ku, tetapi janganlah apa yang aku kehendaki, melainkan apa yang Engkau kehendaki." Jimmy Tjandra mengatakan bahwa dalam doa-Nya, Yesus mengakui kekuasaan Bapa dan menunjukkan iman-Nya bahwa tidak ada yang mustahil bagi Bapa. ${ }^{69}$

Jelas dalam ayat-ayat ini, bahwa Yesus telah meninggalkan pengajaran tentang doa sebagai warisan yang dapat jadikan dasar dalam membangun hubungan pribadi dengan Allah. Yesus memberi teladan kepada murid-murid-Nya bagaimana sikap seseorang dalam menghadapi segala pencobaan tanpa harus menghadapi dengan kekuatan sendiri. Bisa saja Yesus memakai kekuatan-Nya sendiri dalam menghadapi pencobaan itu, namun Sang Guru itu menyadari bahwa ketundukan pada otoritas ilahi itu

${ }^{68}$ Op.cit, Gondowijoyo, hlm. 151

${ }^{69}$ Jimmy Tjandra, Doa yang ditolak Tuhan, (Yogyakarta: Andi Offset, 2013), hlm. 181 
sangat penting. Bukti doa Yesus yang sebagai kekuatan dalam mmenghadapi pencobaan tercatat dalam Markus 1:12-13; Matius 4:1-11; Lukas 4:1-13. Lalu Yesus dapat melewati pencobaan itu oleh karena hubungan-Nya degan Allah begitu kuat melalui doa.

Sehubungan dengan hal ini Mahesh Chavda mengatakan ada tiga rahasia mengapa Tuhan Yesus bisa melewati masa-masa sulit ini, yakni: (1) Yesus dipenuhi dengan Roh Kudus sebelum Ia dibawa oleh Roh Kudus ke padang gurun; (2) Ia berpuasa selama 40 hari dan dicobai; (3) Ia mengakhiri masa pencobaan di padang gurun seperti yang tertulis dalam Injil Lukas 4 dan Injil-injil lainnya. ${ }^{70}$ Menurut hemat penulis, Yesus menang bukan karena semata-mata Dia Anak Allah, namun yang membuat Dia menang adalah memiliki mezbah doa pribadi bersama dengan Bapa-Nya. Kesuksesan pengajaran-Nya tidak terlepas dari praktek doa-Nya setiap waktu sehingga Ia dapat menyembuhkan orang sakit dan mengusir roh jahat. (Mrk. 9:25).

Berdasarkan penjelasan itu, maka kaum pantekosta kharismatik melihat hal-hal itu sangat penting untuk diterapkan dalam kehidupan berjemaat, dengan tujuan adalah supaya jemaat bertumbuh dewasa dalam mengenal Allah melalui doa, sehingga doa semalam suntuk menjadi salah satu bagian yang tidak terlepas dari seluruh rangkai kegiatan ibadah dalam gereja. Percaya tidak percaya itulah ciri khas dari gereja-gereja kharismatik. Sekalipun tidak semua gereja-gereja kharismatik melakukan kegiatan tersebut, namun penulis mengutarakan dalam karya tulis ini bahwa baru-baru ini Gereja Bethel Indonesia Teleios Yogyakarta mengadakan doa semalam suntuk bersama dengan jemaat di pastori, yang diadakan pada tanggal 2 April 2019. Ada beberapa pokok doa yang didoakan pada saat itu yakni mendoakan kesejahteraan Jemaat, mendoakan Bangsa Indonesia serta kegiatan pemilu 17 April 2019.

Baginya, aktivitas doa seperti ini memiliki kekuatan yang supranatural yang tidak bisa dikalahkan dengan apapun. Selain itu, menurut Gondowijoyo (pemilik gua doa emlta) mengatakan ada tiga hal penting yang dihasilkan dari kehidupan doa, yaitu: (1) mengerti kehendak Bapa (Yer. 29:11-14a); (2) mengerti perasaan Tuhan Yesus (Luk. 19:41-44); (3) mengerti pikiran Bapa, Yesus (Anak) dan Roh Kudus (Ikor. 2:6). ${ }^{71}$ Jadi doa Yesus merupakan doa meminta kehendak Allah Bapa yang menjadi tujuan Ia datang ke dunia.

\footnotetext{
${ }^{70}$ Mahesh Chavda, Kuasa dibalik Doa \& Puasa, (Jakarta: Harvest Publication House, 2009), hlm. 19
}

${ }^{71}$ Op.cit, Gondowijoyo, hlm. 36-37 
Bagian sebelumnya telah menyoriti tentang Tuhan Yesus sebagai pendoa. Sub bagian selanjutnya penulis akan menjelaskan Yesus sebagai ahli pengajar berdasarkan perspektif pantekosta kharismatik.

\section{Yesus sebagai ahli Pengajar}

Arti kata "pengajar" menurut kamus besar bahasa Indonesia berarti "orang yang memberi pelajaran."72 Sebagai guru, mengajar adalah tugas utama-Nya, sabab dikatakan dalam Injil Yohanes bahwa "memang Ia datang sebagai guru yang diutus Allah" pasal 3 ayat 2 maka mengajar adalah merupakan tugas-Nya yang terutama. Robert R. Boehlke mengatakan, bahwa merupakan bagian yang amat penting dalam pelayanan Yesus ialah mengajar di mana saja. Kata kerja didaske (mengajar) dalam berbagai bentuk telah dipakai 9 kali dalam Matius sebagai gambaran kegiatan Yesus, 15 kali dalam Markus dan Lukas, dan 8 kali dalam Yohanes, maka "mengajar" itu jelas merupakan bagian yang amat penting dalam pelayanan Yesus...singkatnya, Ia mengajar di mana saja. ${ }^{73}$

Mengajar merupakan tugas yang amat penting dalam pelayanan Yesus, nampak dari setiap jenis pelayanan yang dilakukan Yesus, mengajar merupakan pelayanan yang paling banyak dilakukan-Nya. Pelayanan Tuhan Yesus dalam mengajar lebih sering dilakukan, menunjukkan bahwa Tuhan Yesus sebagai Rabi yang memiliki kualifikasi sempurna dalam melakukan peran-Nya. Menurut Andreas B. Subagyo, "Bila gereja berpikir telah mematuhi perintah terbesar ini tetapi tidak mengajar maka gereja sedang melakukan ketidakpatuhan terbesar." Ditegaskan bahwa Gereja sebagai organisasi yang melaksanakan untuk mewujutkan tugas mengajar. ${ }^{74}$ Pengajaran-Nya sebagai seorang guru, meliputi semua hal yang menjadi tujuan-Nya Ia datang ke bumi. Hal ini dijelaskan oleh A.M. Hunter mengatakan "pengajaran adalah suatu perkara tentang pengalaman hidup setiap hari di mana hampir tidak bisa menerangkan apapun sama sekali kecuali dengan mengatakannya, bahwa pengalaman itu adalah seperti sesuatu yang lain, sesuaatu yang lebih dikenal. Demikianlah perumpamaan Injil sering dimulai."75

${ }^{72}$ Tim Penyusun, Kamus Besar Bahasa Indonesia, (Jakarta: Balai Pustaka, 1995), hlm.14 60.

${ }^{73}$ Robert R. Boehlke, Sejarah Perkembangan Pikiran dan Praktek Pendidikan Agama Kristen, (Jakarta: Gunung Mulia, 1994), hal.

${ }^{74}$ Andreas Bambang Subagyo Mengajar Pesan-Pesan Tuhan. Semarang: STT Baptis, 1999, 26.

${ }^{75}$ A.M. Hunter, Menafsirkan Perumpamaan-Perumpaman, (Jakarta: BPK Gunung Mulia, 1998), hlm. 3 
Salah satu kunci kesuksesan Tuhan Yesus dalam mengajar adalah Dia tahu cara dalam menggunakan pola yang ada. Dalam pengajaran-Nya dapat menarik perhatian banyak orang, hal ini dapat dilihat dalam Injil Markus 10:1 dan Alkitab juga mencatat reaksi orang terhadap pengajaran-Nya. “orang-orang sangat tertarik" (Markus 12:3), "orang banyak yang besar jumlahnya itu senang mendengarkan Dia dengan penuh minat" (Markus 12:37), “orang banyak takjub mendengar pengajaran-Nya' (Mat. 7:28), “orang banyak sangat kagum" (Matius 22:23). Banyak orang selalu mendengarkan pengajaranNya, sebab gaya pengajaran-Nya belum pernah ada di zaman itu. Sekalipun demikian, kebeberhasilan Yesus dalam mengajar tidak terlepas dari pola pengajaran-Nya yang meliputi: sumber bahan dan strategi pengajaran.

1. Sumber dalam pengajaran Yesus.

Salah satu sumber atau bahan pengajaran Yesus pada waktu itu adalah: (a). Firman Allah. Yesus menggunakan Kitab Perjanjian Lama dan Perjanjian Baru sebagai sumber pengajaran-Nya, seperti "Manusia hidup bukan dari roti saja, tetapi dari setiap firman yang keluar dari mulut Allah" (Matius 4:4; Ulangan 8:3) dan Matius 5:5 kita membaca, "Berbahagialah orang yang lemah lembut, karena mereka akan memiliki bumi." Yang terdapat dalam Mazmur 37:11, "Orang-orang yang rendah hati akan mewarisi negri."76 (b). Dunia Alam. Yesus juga menyebut hal yang berhubungan dengan binatang yaitu, domba, kambing, anjing dan burung nazar, hal yang berhubungan dengan tumbuh-tumbuhan, termasuk ragi, lalang, pohon ara, biji sesawi dan kata yang berhubungan cahaya, tanah, pukat, harta yang tersembunyi. Hal-hal tersebut menjadi sumber lukisan yang membuat pengajaran-Nya menjadi menarik dan hidup. Pengajaran apapun akan menjadi lebih efektif apabila memakai lukisan-lukisan yang diambil dari alam, apabila lukisan-lukisan itu dikenal oleh pendengarnya dan dipilih dengan tepat. Sukar dibayangkan apakah yang akan diperbuat Yesus jikalau tiada bahan seperti itu. ${ }^{77}$ (c). Peristiwa-peristiwa hangat. Yesus selalu mengambil kesempatan untuk mengajar dengan mengambil contoh yang ada di sekitar pendengar-Nya. Misalnya, Ia mengambil bahan dari induk ayam yang melindungi anak-anaknya, seorang wanita yang membuat

\footnotetext{
${ }^{76}$ J.M. Price, Yesus guru Yang Agung, (Bandung: Lembaga Literatur Baptis, 2011), hlm. 70

${ }^{77} \mathrm{lbid}$, Price, hlm. 73
} 
adonan, petani yang menaburkan benih, penjaga kebun anggur memotong cabangcabang pokok anggur, penjala ikan, ahli bangunan mendirikan rumah, penjahit menambal pakaian lama, raja bersiap-siap maju ke medan perang. ${ }^{78}$

Berdasarkan penjelasan tentang sumber pengajaran yang digunakan oleh Tuhan Yesus dalam Injil Sinoptik di atas, maka dalam tulisan ini penulis akan menjelaskan bagaimana orang-orang pantekosta kharismatik dalam memanfaatkan sumber-sumber pembelajaran pada saat mengajar dan berkhotbah. Misalnya Pendeta Gereja Bethel Indonesia Teleios Yogyakarta, setiap kali beliau berkhotbah pada awal bulan pasti menggunakan powerpoint, laptop dan tablet sebagai sumber dalam penyampaian pesan kepada umat, tanpa mengabaikan Alkitab sebagai sumber utama. Kelihatannya bukan hanya beliau juga yang memanfaat sumber tersebut, namun ada beberapa pendeta lain juga, seperti Pendeta Gilber Lumoindong dan juga Pendeta Sutadi Rusli, pada saat menjelaskan tentang menjadi orang kristen yang dewasa beliau menggunakan powerpoint. ${ }^{79}$ Selain itu, pada saat penulis mengajar di Program Pascasarjana di STT Kadesi Yogyakarta pada tanggal 25-28 Februari 2019, penulis juga menggunakan powerpoint dalam menjelaskan mata kuliah media dan teknologi pembelajaran. Bagi penulis, sumber belajar merupakan indikator penting dalam proses pembelajaran.

Sekalipun selama ini orang-orang pantekosta kharismatik dianggap hanya mengandalkan kuasa Roh Kudus dan karunia. Namun dalam perjalanannya tidak seperti itu justru kaum pantekosta kharismatik yang dapat mengikuti perubahan zaman termasuk dalam memanfaatkan sumber belajar seperti yang sudah dijelaskan di atas. Jika dibandingkan dengan pengkhotbah orang-orang protestan sangat jauh berbeda. Misalnya di GPIB Cilacap pada bulan Juni 2017 pada saat pendeta menyampaikan firman Tuhan masih menggunakan teks atau diktat yang sudah disiapkan. Selanjutnya, pada saat penulis mengikuti acara pernikahan di gereja BNKP Tanjungpinang pada tanggal 27 April 2019, pada waktu Pendeta menyampaikan firman Tuhan masih menggunakan teks atau diktat. Dengan demikian, tampaknya para pengkhotbah kaum protestan masih terikat dengan administratif, sehingga tidak bisa keluar dari prosedur-prosedur yang sudah ditetapkan.

\footnotetext{
${ }^{78}$ Op.cit, Price hlm. 74

${ }^{79} \mathrm{https}$ ://dbr.gbi-bogor.org/wiki/Khotbah:Menjadi_orang_Kristen_yang dewasa, diunduh pada hari Sabtu, 4 Mei 2019
} 
Sedangkan pengajaran Yesus merupakan contoh bahwa mengajar tidak selalu harus dari buku tetapi bahan pengajaran bisa diambil dari berbagai sumber yang ada di sekitar para pendengar.

\section{Strategi Mengajar Yesus}

Yesus adalah Guru yang sempurna. Salah satu dimensi kesempurnaan-Nya adalah bahwa Ia menggunakan berbagai strategi dalam menyampaikan pengajarannya untuk mencapai tujuan yang diharapkan. Lilik L. Kristianto menulis bahwa strategi yang dilakukan Yesus dalam pengajaran dengan menggunakan beberapa metode. ${ }^{80}$ Yaitu: 1) Metode untuk memenangkan atau memperoleh perhatian (Mat. 4:10,18; 16:13,18). 2) Metode bertanya (Mat. 12:34; 16:13; 21:25-27). 3) Bercerita atau menggunakan ilustrasi (Mat. 7:24-27; 13:1-23; 18:12-14). 4) Metode ceramah (Mat. 5-7; 24-25). 5) Metode menggunakan benda atau objek (Mat. 6:25-31; 13-17; 18:1-6). 6) Metode menggunakan model (Mat. 6:5-13). Tan Giok Lie mengklasifikasikan ada enam strategi pengajaran yang dilakukan Yesus. Yaitu: 1) Identification learning (Mat. 13; 16:5-12; 8:11-14). 2) Inquiry learning (Mat. 5:1-20). 3) Structured modeling (Mat. 6:5-13 bd. 14:23). 4) Spontaneous modeling (Mat. 8:23-27; 8:28-34;21:12-17. 5) Consequence learning (Mat. 19:16-26). 6) Cue learning (Mat. 19:16-26). ${ }^{81}$

Berdasarkan penjelasan dan uraian di atas, penulis melihat bahwa salah satu kunci kesuksesan seorang pengkhotbah atau pengajar seperti yang dilakukan oleh Tuhan Yesus dalam Injil Sinoptik adalah dapat menggunakan strategi dengan baik. Salah satu strategi mengajar yang digunakan oleh Tuhan Yasus, yakni strategi mengajar direct instruction. Menurut Eggen dan Kauchak, strategi pembelajaran direct instruction merupakan strategi pembelajaran yang di dalamnya pengajar menyediakan urutan penjelasan dan melalui pemeriksaan dalam konsep dengan banyak memberikan contoh-contoh ilustrasi

${ }^{80}$ Paulus Lilik Kriatianto, Prinsip dan Praktik Pendidikan Agama Kristen (Yogyakarta: Yayasan Andi, 2008), hal. 14.

81Identification learning adalah cara belajar efektif apabila pengajaran membangun jembatan dari suatu informasi yang sama sekali belum dipelajari murid dengan cara memberikan terlebih dahulu informasi yang telah diketahui oleh murid. Inquiry learning adalah cara belajar dengan mengajukan pertanyaan kepada murid agar mereka berpikir. Structured Modeling adalah cara belajar dimana murid belajar dari guru yang sudah berencana untuk menunjukkan suatu tingkah laku tertentu yang sepatutnya diteladani oleh murid. Spontaneous modeling cara belajar dimana seorang guru tanpa rencana sebelumnya menunjukkan suatu tingkah laku tertentu untuk dilihat dan diamati muridNya agar belajar sesuatu. Consequence learning ialah cara belajar yang membuat murid belajar sesuatu setelah mengalami suatu konsekuensi tertentu. Cue learning cara yang selalu membantu murid untuk mengingat makna yang penting yang terkandung dalam suatu objek tertentu. (Tan Giok Lie, "Yesus “Guru Agung" Sebagai Model Alkitabiah Bagi Guru Kristen Masa Kini “ Sola Scriptura dan Pergumulannya Masa Kini., peny., Togardo Siburian (Bandung: STT Bandung, 2005), 70). 
pada bagian akhir. ${ }^{82}$ Yesus ketika mengajar murid-muridnya sering menggunakan strategi pengajaran direct instruction. Yesus memberikan pengetahuan kepada muridmurid-Nya. Ia menguasai bahan pengajaran dengan baik, menyampaikan kepada muridmurid-Nya, memberikan penjelasan dengan jelas, memberikan pelatihan dan menerapkan konsep materi tersebut dalam mengajar. Beberapa metode yang digunakan Yesus ketika mengajar secara langsung antara lain: metode ceramah atau khotbah Matius 5-7, metode bercerita dan metode demonstrasi.

Berdasarkan penjelasan tersebut di atas dapat disimpulkan bahwa orang-orang pantekosta kharismatik pada umumnya sangat mahir dalam menggunakan strategi mengajar atau berkhotbah. Hal ini dapat lihat pada saat khotbah. Misalanya Pendeta Gilbert Lumoindong, pada saat beliau melayani di Ibadah Paskah 21 April 2019 di Gereja Bethel Indonesia Glow berkhotbah sambil jalan-jalan dan tanya jawab kepada jemaat. ${ }^{83}$ Dengan kata lain, orang-orang pantekosta kharismatik ini memiliki ciri khas dibandingkan dengan orang-orang pantekosta pada umumnya. Salah satu ciri khas yang ditampilkan oleh kedua tokoh tersebut di atas adalah tidak terikat dengan tempat pada saat menyampaikan firman Tuhan kepada jemaat. Artinya bisa keluar dari mimbar tersebut dan mendekati jemaat.

Lain dengan gereja-gereja protestan seperti HKBP, GKJ, GMIT dan BNKP di mana para Pendeta harus berdiri di mimbar yang memiliki jarak dengan jemat sekitar 6-8 meter dan tingginya mimbar diperkirakan 2-3 meter. Para pelayan mimbar ini tidak bisa kemana-mana, tidak seperti kaum pantekosta kharismatik. Hal ini pernah penulis mengalaminya, di mana penulis diundang khotbah oleh Ikatan Keluarga Nias Yogyakarta pada tanggal 21 Oktober 2018 bertempat di GKJ Ngologaten di belakang Ambarukmo. Pada saat penulis khotbah sepertinya ada yang kurang karena penulis tidak biasa menggunakan mimbar yang tinggi dan jauh dari jemaat. Jadi menurut hemat penulis dengan kejadian ini, pesan yang disampaikan kepada jemaat tidak sampai karena strategi yang dipakai adalah hanya ceramah dan satu arah sehingga pendengar menjadi bosan.

Selain strategi mengajar secara langsung yang digunakan oleh Tuhan Yesus. Tuhan Yesus juga menggunakan strategi mengajar tidak langsung (Indirect Instruction). Dalam strategi pembelajaran tidak langsung, peserta didik dijadikan sebagai pusat pembelajaran. Pembelajaran ini melibatkan siswa untuk melakukan observasi dan

\footnotetext{
${ }^{82}$ Paul Eggen dan Don Kauchak, Strategi dan Model Pembelajaran, (Jakarta: Indeks, 2007), 363.
}

${ }^{83} \mathrm{https}: / /$ www.youtube.com/watch?v=Fj1ec9RFLNk, diunduh pada tanggal 9 Mei 2019 
penyelidikan. Dalam strategi ini bahan pelajaran dicari dan ditemukan sendiri oleh peserta didik melalui berbagai aktivitas. ${ }^{84}$ Yesus menggunakan strategi pembelajaran tidak langsung untuk mencapai tujuan yang diharapkan. Strategi yang dilakukan ini antara lain tampak ketika Yesus menjelaskan siapa Dia dalam Matius 16:13-20. Pengajaran ini dimulai dari permintaan tanda yang menunjukan bahwa Yesus adalah Mesias oleh orang Farisi dan orang Saduki (Mat. 16:1).

Jika dibawa dalam konteks mengajar saat ini sering kali para guru atau dosen melakukan strategi mengajar tidak langsung seperti yang dilakukan oleh penulis pada saat mengajar di semester dua di STT Kadesi Yogyakarta pada tanggal 8 Mei 2019, penulis mengajak mahasiswa membaca Matius 3 tentang Yohanes Pembaptis; dalam teks itu dikatakan bahwa makanan Yohanes Pembaptis adalah belalang dan madu hutan. Sebagai objek pengamatan mahasiswa adalah apakah benar makanan Yohanes Pembaptis itu adalah belalang seperti yang dijual oleh masyarakat Gunung Kidul. Jadi tujuan mengajar tidak langsung ini adalah untuk menunjukkan kepada mahasiswa objek yang ada dalam teks sesuai dengan kebenaran Alkitab.

\section{Strategi Mengajar Empirik}

Strategi mengajar empirik disebut juga dengan strategi mengajar melalui pengalaman (experiential). Penekananan dalam strategi pembelajaran ini adalah pada proses belajar bukan pada hasil belajar. Penekananan dalam strategi pembelajaran ini adalah pada proses belajar bukan pada hasil belajar. Tuhan Yesus pun melakukan strategi pengajaran melalui pengalaman guna mencapai tujuan yang diharapkan. Hal ini dapat dilihat melalui percakapan Yesus dengan orang muda yang ingin ke surga (Mat. 19:1626). Ia menggunakan pengalaman orang muda yang kaya untuk menjelaskan tentang kepastian cara untuk memperoleh hidup yang kekal atau tidak mudah orang untuk masuk kedalam Kerajaan Surga. Dalam pengajaran-Nya, ini dimulai dari permasalahan yang dihadapi oleh orang muda tentang ketidakjelasannya akan perbuatan apa saja yang bisa membuat orang memiliki hidup yang kekal (Mat.19:17).

Apabila strategi pembelajaran empirik yang dilakukan oleh Yesus dicermati, maka akan diperoleh beberapa metode pengajaran yang dilakukan oleh Yesus. Metode tersebut

${ }^{84}$ Wina Sanjaya, Strategi Pembelajaran Berorientasi Standar Proses Pendidikan, (Jakarta: Prenadamedia Group, 2006), hal. 129. 
adalah metode kasus (case method) dan pembelajaran berdasarkan masalah (problem based learning). Kedua metode tersebut akan dijelaskan seperti di bawah ini:

Pertama, case method. Metode kasus adalah cara menyajikan pelajaran dengan memanfaatkan kasus yang ditemui sebagai materi pelajaran, kemudian kasus tersebut dibahas bersama untuk mendapatkan penyelesaian atau jalan keluar. ${ }^{85}$ Menurut A. Majid, kasus yang digunakan adalah kasus yang nyata. ${ }^{86}$

Kedua, metode problem based learning. Problem based learning adalah suatu cara menyajikan pelajaran dengan mendorong siswa untuk mencari dan memecahkan suatu masalah dalam rangka mencapai tujuan pengajaran. ${ }^{87}$ Yesus menggunakan masalah sebagai dasar pengajaran. Masalah yang digunakan sebagai materi pengajaran adalah masalah sehari-hari yang sering ditemui murid-murid dan masyarakat pada waktu itu. Masalah tersebut digunakan sebagai materi untuk mencapai tujuan yang diharapkan.

Berdasarkan penjelasan dan uraian di atas, penulis berpendapat bahwa mengajar secara empirik tidak hanya terjadi pada waktu Tuhan Yesus berkhotbah dan saat mengajar murid-murid-Nya, namun mengajar secara empirik sering kali dilakukan oleh kaum orang-orang pantekosta kharismatik dalam pelayanan firman Tuhan. Misalnya Daud Tony (Mantan dukun bertobat jadi Pendeta), pada saat beliau berkhotbah di GSJS Grand City Surabaya, sebelum menyampaikan firman Tuhan, beliau menceritakan bagaimana pengalaman pribadinya ketika berjumpa dengan Tuhan Yesus. Inti daripada khotbahnya adalah menyampaikan tentang kebaikan Tuhan kepada setiap orang. Tuhan tidak melihat latar belakang seseorang untuk dipakai oleh Tuhan sebagai alat-Nya. ${ }^{88}$ Artinya Daud Tony sedang membawa umat Tuhan untuk berpengalaman dengan Tuhan dalam setiap masalah yang ada. Kesaksian hidup bersama dengan Tuhan sangat menolong seseorang untuk menjadi dewasa secara rohani.

Hal-hal seperti ini sudah menjadi penekanan utama bagi kaum pantekosta kharismatik pada saat pelayanan di mimbar. Penulis mengamati bahwa dasar pendekatan dalam khotbah menggunakan masalah sehari-hari yang sering ditemui oleh jemaat dan masyarakat pada umumnya. Metode seperti ini sering kali penulis menggunakannya pada saat khotbah di gereja, karena setiap akhir bulan pasti penulis

\footnotetext{
${ }^{85}$ Roestiyak NK, Strategi Belakar Mengajar, op.cit., 94.

${ }^{86}$ A. Majid, Strategi Pembelajaran, op.cit., 94.

${ }^{87}$ Hamdani, Strategi Belajar Mengajar, (Bandung: Pustaka Setia, 2011), hal. 84

${ }^{88} \mathrm{https}: / /$ www.youtube.com/watch?v=aB6TJoIbWIo, diunduh Pada Tanggal, 16 Mei 2019
} 
mendapat jadwal sebagai pengkhotbah internal di Gereja Bethel Indonesia Teleios Yogyakarta. Menurut hemat penulis, menggunakan strategi empirik dalam mengajar dan berkhotbah sangat tepat dan sesuai dengan kebutuhan jemaat. Penulis menceritakan bagaimana pertolongan Tuhan selama mengikuti proses perkuliahan di Yogyakarta mulai dari S1-S3. Penulis tidak pernah membayangkan bisa mencapai titik itu karena penulis bukan dari keluarga mampu. Dalam pengalaman bersama Tuhan sebaiknya yang diceritakan itu bukan tentang diri sendiri tetapi menceritakan bagaimana Allah berperkara atas setiap persoalan yang ada serta pertolongan-Nya. Namun dalam perjalanannya sering kali para pengkhotbah pantekosta kharismatik itu bukan Tuhan yang diceritakan tetapi diri sendiri sehingga tidak sedikit ditemui di lapangan menjadi orang-orang sombong rohani.

Lepas dari benar tidaknya kesaksiannya itu, namun yang menarik dari aliran ini adalah sebelum berkhotbah biasanya bertanya dulu kepada Tuhan. Inilah ciri-ciri pengkhotbah dari pantekosta kharismatik. Tidak hanya bertanya kepada Tuhan, namun para pengkhotbah pantekosta kharismatik tersebut memberi kesempatan kepada jemaat untuk bertanya, berpikir, mengemukakan pendapat, dan mengambil kesimpulan atas apa yang didapat dalam nats Alkitab. Alkitab menulis bahwa Tuhan Yesus mendidik muridmurid-Nya untuk aktif dalam memahami kebenaran yang Ia sampaikan. Dengan demikian, tujuan dari mengajar secara empirik adalah pengajaran melalui pengalaman hidup dapat mencapai tujuan yang diharapkan dan jemaat mengambil bagian dalam memecahkan masalah yang dihadapi.

\section{Strategi Mengajar Melalui Media}

Yesus adalah Guru Agung. Guru yang Agung seharusnya mengajar murid-murid yang sempurna. Sebagai Guru Agung, Yesus memahami bahwa murid-murid yang sangat heterogen tersebut memiliki daya tangkap dalam yang berbeda-beda dalam menerima materi yang diajarkan. Gaya belajar murid-murid Yesus berbeda-beda. Gaya belajar adalah kombinasi dari menyerap, mengatur, dan mengolah informasi materi pembelajaran. Susan Grace Widiono mengutip pendapat Bobbi DePorter menjelaskan ada tiga jenis gaya belajar, yaitu visual, auditori, dan kinestetik. ${ }^{89}$ Media yang digunakan 
Yesus untuk mengajar dalam Injil Matius antara lain: Pertama, Media pembelajaran langsung. Media pembelajaran langsung dapat dibedakan menjadi dua bagian, yaitu pengalaman langsung dan media yang berupa benda asli. Media pengajaran dengan pengalaman langsung merupakan pengalaman yang diperoleh peserta didik sebagai hasil dari aktivitas mereka sendiri. ${ }^{90}$ Media pengajaran dengan pengalaman langsung ini tampak ketika mukjizat-mukjizat yang dilakukan oleh Yesus untuk mengajar tentang keIllahian-Nya dengan memberi makan 4000 orang.

Berdasarkan penjelasan media yang dipakai oleh Tuhan di atas, maka penulis mengamati bahwa hamba-hamba Tuhan di kalangan orang-orang pantekosta kharismatik seringkali menggunakan media sebagai alat dalam mengimpartasikan kuasa Allah melalui ibadah kesembuhan, pengurapan dan pelepasan dengan cara mengundang jemaat datang kedepan atau altar chord. Salah satu media yang sering dipakai oleh hamba Tuhan dalam melakukan kesembuhan, pengurapan dan pelepasan adalah minyak urapan. Ada beberapa Pendeta yang sering melakukan ibadah kesembuhan dengan menggunakan minyak urapan antara lain: (1) Pendeta Ari Suksmono, GJKI Milenium Damai Solo. Gereja ini setiap minggu melakukan ibadah kesembuhan dan melalui ibadah tersebut tidak sedikit orang-orang yang mengalami mujizat Tuhan; (2) Pendeta Yesaya Pariadji, Gereja Tiberias Jakarta. Gereja ini cukup terkenal dalam menggunakan minyak urapan, setiap ibadah pasti jemaat dioleskan dengan minyak urapan dengan alasan supaya Tuhan menyembuhkan dari sakit penyakit.

Media-media ini menjadi salah satu objek yang dapat menyembuhkan orang dari sekit penyakit, karena dibeberapa kesempatan dalam ibadah sering terjadi lawatan Tuhan ketika orang lumpuh didoakan bisa berdiri dan jalan, sehingga ketika terjadi impartasi kuasa Tuhan melalui kesembuhan tersebut maka tidak sedikit orang yang percaya dengan minyak urapan dan tidak sedikit juga orang-orang menolak minyak urapan. Bukan hanya menolak namun menuduh bahwa gereja-gereja yang memakai minyak urapan adalah gereja sesat. Kelompok kaum protestan misalnya sangat memprotes dengan ritual-ritual yang dilakukan oleh gereja-gereja yang mempercayai kuasa dari minyak urapan. Sebab konsep pemberian minyak urapan dalam Perjanjian Lama dan Perjanjian Baru bukan seperti itu, karena kuasa Tuhan tidak dibatasi dengan

${ }^{90}$ Wina Sanjaya, Perencanaan dan Desains Pembelajaran, (Jakarta: Prenada Media Group, 2015), 200. Wina Sanjaya, 
salah satu media saja. Akhirnya minyak urapan sudah menjadi perdebatan panjang di kalangan para teolog di lingkungan orang-orang Kristen pada umumnya.

Kedua, media pembelajaran tidak langsung atau tiruan. Media tidak langsung atau tiruan adalah media yang berupa peristiwa atau benda sudah dibentuk sedemikian rupa sehingga hanya dapat didengar dan disaksikan. ${ }^{91}$ Media pengajaran tidak langsung digunakan oleh Yesus dalam Injil Matius antara lain dengan perumpaman-perumpamaan untuk mengajarkan suatu hal. Yesus banyak sekali mengajarkan perumpamaan kepada peserta didik yang mengikutinya. Ia menggunakan perumpamaan untuk menjelaskan sebuah pemahaman. Berikut ini penjelasan tentang media tidak langsung yang digunakan oleh Yesus dalam Injil Matius, yakni: (1). Yesus menggunakan perumpamaan tentang penabur (Mat. 13:1-23). (2). Yesus menggunakan perumpamaan lalang (Mat. 13:24-30). (3). Biji sesawi (Mat. 13:31-35). (4). Gadis yang bodoh dan gadi yang bijaksana (Mat. 25:113). (5). Mutiara (Mat. 13:44-46). (6). Pukat (Mat. 13:47-52). Dalam pengajaran-Nya tentang Kerajaan Surga, Yesus memakai alat peraga pukat. Pukat adalah jaring (jala) besar dan panjang untuk menangkap ikan. ${ }^{92}$ (7). Talenta (Mat. 25:14-30).

Berdasarkan penjelasan tentang media tidak langsung yang dipakai oleh Tuhan Yesus di atas, maka penulis akan menjelaskan media tidak langsung yang sering digunakan para pengajar dan pengkhotbah. Para pengkhotbah sering kali menggunakan media tidak langsung. Misalnya ketika Bapak Agung Wijawa membahas tentang “Arkeologi Biblikal” di resto Joglo Harmoni di Ngalik pada tanggal 26 April 2019. Beliau ini adalah salah satu ahli arkeologi yang sangat aktif dalam memberi seminar-seminar tentang arkeologi di berbagai tempat seperti gereja, kampus dan komunitas yang lain. Sejauh pengamatan penulis dalam kegiatan ini, bagi penulis sangat menolong para audiens ketika menerima tentang penjelas arkeologi biblikal ini, karena beliau menggunakan media-media yang cukup dimengerti seperti foto asli ketika beliau bersama dengan dosennya dan teman-teman mahasiswanya pada saat membersihkan salah satu fosil yang ada.

Mahasiswa alumni UGM dan STTII ini sangat memanfaatkan beberapa gambar lain yang diakses dari internet yang dapat memberi penjelasan tentang apa yang pernah terjadi dahulu kala. Sekalipun media ini sangat terbatas tetapi paling tidak menolong

\footnotetext{
${ }^{91}$ B.S. Sidjabat, Mengajar Secara Profesional, op.cit., 302.

${ }^{92}$ Tim Penyusun Kamus Besar Bahasa Indonesia, Kamus Besar Bahasa Indonesia, op.cit., 95.
} 
setiap para pendengar untuk menangkap setiap pesan yang ada. Lepas dari benar atau tidaknya foto dan media yang digunakan, namun yang pasti media tidak langsung ini telah dimanfaatkan sebagai alat bantu untuk menggambarkan setiap kejadian yang ada. Dengan demikian dapat disimpulkan bahwa media langsung dan tidak langsung salah satu strategi yang harus dipakai oleh para pengajar saat ini, sebab tanpa media maka informasi yang akan disampaikan sangat sulit untuk diterima. Itulah sebabnya dalam kajian yang pernah kami tulis, penulis mengatakan "media adalah sebagai alat komunikasi yang digunakan dalam proses belajar mengajar". ${ }^{93}$

\section{Kesimpulan}

Dalam perkembangan gereja khususnya masa Reformasi memberi keuntungan kepada para elit gereja untuk mengajar sehingga, para Burteros, Imam, Bapak-Bapak gereja dan tokoh-tokoh di lingkungan organisasi gereja saja yang merasa memiliki kedudukan istimewa untuk mengajar jemaat. Kritiknya adalah keistimewaan itu tidak dimiliki oleh kaum awam yang banyak terjun langsung dalam bidang pelayanan khususnya pengajaran seperti yang dilakukan oleh kaum pantekosta. Kelompok ini yang dinamai dengan kaum Primus inter pares. Keteladanan yang ditunjukkan oleh Tuhan Yesus dan diikuti oleh orang-orang pantekosta seperti contoh yang telah dipaparkan sebelumnya hendak mengatakan bahwa dalam perkembangan reformasi itu bukan hanya milik kaum protestan. Orang-orang pantekosta sekarang ini telah menjadi pelaku reformasi gereja di dalam hal berdoa dan pengajaran. Jika dahulu reformasi itu diperbolehkan siapa saja menjadi pembawa Injil dan Pengajar dan cara mengajarnya menjadi dinamis, tetapi pada kenyataan orang-orang protestan sesudah dijelaskan sebelumnya berdasarkan kajian dan data empiris tidak ada perubahan sejak Martin Luther membuat Reformasi, namun dalam perjalanannya orang-orang pantekosta kharismatik sangat dinamis.

Keteladanan Tuhan Yesus sebagai pendoa dan pengajar berdasarkan Injil Sinoptik menegaskan bahwa tidak ada alasan apa pun bagi kaum pantekosta untuk menyangkal bahwa Tuhan Yesus sebagai kajian utama dalam proses pembelajaran. Hal

${ }^{93}$ Talizaro tafonao, Peranan media pembelajaran dalam meningkatkan Minat belajar mahasiswa. Dalam Jurnal Komunikasi Pendidikan, Vol.2 No.2, Juli 2018, hlm. 107 
ini nampak dalam penjelasan sebelumnya bahwa orang-orang pantekosta sekarang ini sangat kreatif dan dinamis dalam memanfaatkan berbagai sumber dan juga dalam menggunakan strategi mengajar melaui perkembangan teknologi yang tidak terjebak pada sistem administrasi yang kaku.

Tulisan ini bisa menjadi sebagai kontribusi bagi kaum pantekosta terhadap kemajuan pendidikan dan gereja pada umumnya dengan menggunakan studi analisis tentang keteladanan. Namun, kajian ini ingin memberi sumbangan analisis bukan lagi dalam keteladanan Yesus secara biografis seorang tokoh, tetapi sumbangannya dalam hal aktifitas seorang tokoh yang mampu mengubah tantangan sosial di zamannya dan hari ini. Dengan demikian, kajian studi pantekosta ini bisa memberi sumbangan konseptual yakni aktivisme tokoh-tokoh populer Kristen kaum panteskosta yang meneruskan semangat reformasi dalam hal pengajaran yang tidak lagi bersifat elitis dan strukturalisme.

\section{Daftar Pustaka}

Boehlke. Robert R., Sejarah Perkembangan Pikiran dan Praktek Pendidikan Agama Kristen, Jakarta: Gunung Mulia, 1994

Clandinin, D.J. \& Conelly, F.M. Narrative Inquiry Experience and Story in Qualitative Research. San Fransisco: Jossey-Bass Publishers, 2000.

Chavda. Mahesh, Kuasa dibalik Doa \& Puasa, Jakarta: Harvest Publication House, 2009

Gondowijoyo, Sekolah Doa, Yogyakarta: Andi Offset, 2010

Hunter. A.M., Menafsirkan Perumpamaan-Perumpaman, Jakarta: BPK Gunung Mulia, 1998

Hamzah B. Uno, Profesi Kependidikan: Problema, Solusi, dan Reformasi Pendidikan di Indonesia, Jakarta: Bumi Aksara, 2008

Hamdani, Strategi Belajar Mengajar, Bandung: Pustaka Setia, 2011

Hayford. Jack, Doa Mengalahkan Kemustahikan, Yogyakarta: Andi Offset, 2008

Herlianto., Teologi Sukses, Jakarta: BPK Gunung Mulia, 2006

Isnawati. Nurlaela, Guru Positif-Motivatif, Yogyakarta: Laksana, 2010

J.M. Price, Yesus guru Yang Agung, Bandung: Lembaga Literatur Baptis, 2011

Kriatianto. Paulus Lilik, Prinsip dan Praktik Pendidikan Agama Kristen Yogyakarta: Yayasan Andi, 2008

Lie. Tan Giok, "Yesus "Guru Agung” Sebagai Model Alkitabiah Bagi Guru Kristen Masa Kini “ Sola Scriptura dan Pergumulannya Masa Kini., peny., Togardo Siburian Bandung: STT Bandung, 2005

Maward. Rizal , Metodologi Penelitian Pendekatan Naratif Fenomenology, Surabaya: Universitasi Airlangga, 2017

Munroe. Myles., The Purpose and Power of Praise \& Worship, USA: Destiny Image Publisher Inc, 2000

Oh. Robert. Sukwan, The Prayer Drive Life, Yogyakarta: Andi Offset, 2010

Paul Eggen dan Don Kauchak, Strategi dan Model Pembelajaran, Jakarta: Indeks, 2007

Rahner. Karl, Encyclopedia of theology: A concise Sacramentum mundi, USA: Continum International Publishing Inc, 1975

Sanjaya. Wina, Perencanaan dan Desains Pembelajaran, Jakarta: Prenada Media Group, 2015 
Sidjabat. B. Samuel, Strategi Pendidikan Kristen Suatu Tinjauan Teologis-Filosofis Yogyakarta: Andi, 1999

Samuel. Wilfred J., Kristen Kharismatik, Jakarta: BPK Gunung Mulia, 2006

Sutanto. Hasan, Perjanjian Baru Interlinear Yunani-Indonesia dan Konkordansi Perjanjian Baru II, Jakarta: LAI, 2004

Suparlan, Menjadi Guru Efektif, Yogyakarta: Hikayat, 2005

Sabdono. Erastus, Menemukan Kekristenan Yang Hilang, Jakarta: Rehobot Literature, 2014

Stalker. James, Masa Hidup Yesus Kristus, Malang: Gandum Mas,1991

Subagyo. Bambang. Andreas, Mengajar Pesan-Pesan Tuhan. Semarang: STT Baptis, 1999

Tong. Stephen, Arsitek Jiwa II, Surabaya: Momentum, 2008

Tim Penyusun Kamus Pusat Bahasa, Kamus Besar BahasaIndonesia, Jakarta: Balai Pustaka, 2001

Tim Penyusun, Kamus besar Bahasa Indonesia, Jakarta: Balai Pustaka, 1995

Tafsiran Masa Kini 3, Matius-Wahyu, Jakata: Yayasan Komunikasi Bina Kasih/OMF, 1994

Tjandra. Jimmy, Doa yang ditolak Tuhan, Yogyakarta: Andi Offset, 2013

Tafonao. Talizaro, Peranan media pembelajaran dalam meningkatkan Minat belajar mahasiswa. Dalam Jurnal Komunikasi Pendidikan, Vol.2 No.2, Juli 2018

Tung. Khoe Yao, Terpanggil Menjadi Pendidik Kristen Yang Berhati Gembala, Yogyakarta: Andi Offset, 2016

\section{Internet}

https://news.okezone.com/read/2018/12/08/338/1988672/ratusan-ribu-jemaat-hadiri-acara-natal-digbk-350-aparat-gabungan-diterjunkan, diunduh pada hari Jumat, 12 April 2019

https://www.tiberias.or.id/events/rally-awal-kkr-tahun-2019-tiberias-medan-pajus-padang-bulan-25januari-2019-jam-18-30-wib--45, diunduh pada hari Jumat, 12 April 2019.

https://wartanasrani.com/detailpost/manmin-center-jakarta-dan-formag-jaktim-kerjasama-gelar-kkrmujizat-kesembuhan-dan-penyembahan-2018, diunduh pada hari Jumat, 12 April 2019

https://dbr.gbi-bogor.org/wiki/Khotbah:Menjadi orang Kristen yang dewasa, diunduh pada hari Sabtu, 4 Mei 2019

\section{Tentang penulis}

Talizaro Tafonao berafiliasi di Sekolah Tinggi Teologi KADESI Yogyakarta, SlemanYogyakarta. Email: talizarotafonao@gmail.com. 